Article

\title{
Socially Responsible Human Resource Management as a Concept of Fostering Sustainable Organization-Building: Experiences of Young Polish Companies
}

\author{
Edyta Bombiak *(1) and Anna Marciniuk-Kluska *(i) \\ Faculty of Economic and Legal Science, Siedlce University of Natural Sciences and Humanities, Konarskiego 2, \\ 08-110 Siedlce, Poland \\ * Correspondence: edyta.bombiak@uph.edu.pl (E.B.); anna.marciniuk-kluska@uph.edu.pl (A.M.-K.); \\ Tel.: +025-643-17-09 (E.B.); +025-643-17-09 (A.M.-K.)
}

Received: 16 December 2018; Accepted: 13 February 2019; Published: 17 February 2019

check for updates

\begin{abstract}
There has been increased interest over recent years in socially responsible human resource management (SRHRM) oriented at developing good relations with employees as a function fostering sustainable organization-building. This is a consequence of our awareness of the fact that employees and personnel processes play a vital role in translating the policy of sustainable development into practice. The objective of this research has been to diagnose the activity of young Polish enterprises in the area of SRHRM as an important corporate social responsibility (CSR) component and to assess relations between SRHRM practices and the sustainable development of organizations. The studies conducted on a representative sample of 150 entities demonstrate both the scope of SRHRM practical implementation and the fields which have disparity in this respect. It has been determined that SRHRM practices are quite frequently adopted by young Polish enterprises. Research has shown that there is a correlation between the assessment of the relationship of SRHRM practices with the sustainable development of organizations and their practical implementation. It has been established that the higher the assessment of the strength of the relations of a given practice, the more often it is implemented in the enterprises studied. Simultaneously, the research has demonstrated a low level of maturity with respect to SRHRM implementation, as evidenced by the adoption of basic practices.
\end{abstract}

Keywords: sustainability development; corporate social responsibility; sustainable enterprises; young companies; socially responsible human resource management

\section{Introduction}

In contemporary knowledge economies, one of the crucial elements determining an organization's ability to create added value, and hence its long-term competitiveness, is skillful interaction with one's surroundings [1]. What is expected from today's businesses, however, is not only for them to generate profits but also to limit and reduce their negative impact on the environment and to address threats to our civilization [2]. In response to higher global social awareness as well as the sensitivity of interested parties, the number of organizations which have based their strategies on sustainable development principles is growing [3].

Sustainable development is a present-day idea of civilizational development, born out of the necessity to mitigate and counteract the adverse impacts of economic growth. It is the kind of development that aims to satisfy the needs of present generations while preserving the ability of future generations to meet their own aspirations [4]. Its mechanism is built around the pursuit of three primary goals [5-8]: 
(1) Ecological—which involves a reduction of environmental degradation;

(2) Economic - expressed by satisfying basic material human needs with the application of technology and techniques which do not destroy the environment;

(3) Social - which assumes the maintenance of a social minimum (eradication of hunger and poverty), health protection, development of human spiritual sphere (culture), safety and education.

A consideration of the above mentioned three categories of objectives is referred to as the "triple-bottom line" [9]. The concept highlights that social, economic and environmental goals are interrelated and mutually reinforcing [10].

Therefore, the idea of sustainable development has three characteristic features: sustainability, durability and self-sustainability. Sustainability involves the need to maintain a balance between developmental needs and the need to protect the environment. Durability requires the provision of access to environmental resources. Self-sustainability draws attention to the interdependence of economic, environmental and social factors in the stimulation of a long-term economic growth [11].

The application of the principles of sustainable development entails profound consequences at the microeconomic level. For the idea to be implemented and to assess its effectiveness, business entities need to account not only for economic aspects but also for social and environmental criteria [12]. Consequently, this means support should be provided to organizations which are socially responsible, environmentally friendly and which promote economically valuable solutions as part of their business activities [13]. A tool that fosters sustainable organization-building is the concept of CSR.

CSR refers to a firm fulfilling its legal, economic, ethical, and philanthropic responsibilities to society [14]. The ISO 26000 standard (International Organization for Standardization) defining social responsibility as the responsibility of an organisation for the impact of its decisions and activities on society and the environment, through transparent and ethical behaviour which contributes to sustainable development, including the health and well-being of society [10]. Hart defines CSR as "the company's considerations of and response to issues above the narrow economic, technical and legal requirements of the company to accomplish social and environmental benefits alongside with the traditional economic benefits which the company seeks to achieve" [15].

CSR is a set of activities which serves the implementation of the sustainable development strategy at the microeconomic level [1]. It is a business model based on the development of long-term relations with all participants of the socio-economic system, having regard for their diversity and developmental needs. Thus, CSR stands for a rejection of the strategy oriented purely towards the interests of the owner of the capital [1]. According to this concept, the objective of an enterprise is to create value for all stakeholders, which allows sustainable development and encourages the ongoing involvement of social partners [16]. It is reflected by the voluntary adoption of these expectations into company strategy, which leads not only to economic benefits but also social effects.

CSR concentrates on the organization, yet it is strictly connected to sustainable development [10]. The connection between CSR and sustainable development is emphasized by the definition formulated by the World Bank, stating CSR is the commitment of the business in contributing to the sustainable development through the cooperation of human employees, their families, local communities and society, aimed at improving the quality of life and thus both business and social development [17]. The CSR concept has been defined by the World Business Council for Sustainable Development as "the commitment of business to contribute to sustainable economic development, working with employees, their families, the local community, and society at large to improve their quality of life" [18]. The stated purpose of CSR is "minimizing compromise and maximizing synergies" resulting from company interactions with the economic, community and natural environment where it operates [19]. According to ISO 26000, caring for the compliance with law is especially important when implementing CSR [10]. Also, Cohen at al. [20] underline that respecting the labor law is the starting point for SRHRM. Therefore, it can be concluded that complying with legal regulations is a necessary but not sufficient condition for CSR. 
In recent years one can see a kind of integration of CSR and corporate governance (CG) [21]. According to ISO 26000 corporate governance is a system enabling an organization to take and implement decisions serving the realization of its goals. The corporate governance framework is there to encourage the efficient use of resources and equally to require accountability for the stewardship of those resources [22]. The governance mechanism is multidimensional and should ensure that stakeholders interests are protected in all respects. There should be complete transparency about the activities of the company. The conduct of the company should be in line with the legal and ethical framework. That is why some authors believe that CSR is a part of corporate governance [21,22]. Firms use governance mechanisms, along with CSR engagement, to reduce conflicts of interest between managers and non-investing stakeholders. When managers use CSR activities to resolve conflicts between managers and various stakeholders, CSR engagement enhances firm value and performance [23]. CSR and CG have some common ground. Both concepts relate to the general relationships of an enterprise with its internal and external environment, accept the company's responsibility, and aim at ensuring a stable performance and good communication with stakeholders [24]. That is why they can complement each other in heading towards sustainable development of the organization. Giroud and Mueller [25], Coles et al. [26], Core and Guay [27], $\mathrm{Li}$ [28] write more about corporate governance and its impact on sustainable development and its connected practices.

Even though the ideas of sustainable development and CSR have been evolving over recent decades [29], in published works concerning the matter focus is mainly placed on aspects related to the environmental and economic dimensions, whereas far less attention is paid to the social dimensions of sustainable development [30,31]. It seems so far that the full potential of human resource management (HRM) within the process of sustainable organization-building and the attainment of sustainable development goals is yet to be revealed [32]. Therefore, in recent years there has been an increase in interest from both theoreticians and practitioners in the concept of sustainable human resource management (SHRM). As highlighted by authors dealing with SHRM, personnel processes and HR leaders play vital roles in translating the policy of sustainable development into practice [33-40]. Thanks to SHRM support, companies may attain their sustainable development goals more effectively [31,41].

It should be noted that the SHRM concept is a result of connecting HRM with the idea of sustainable development $[20,42,43]$. The idea emphasizes the need to develop the objectives of the personnel function in a broader manner-not only in categories of economic interest, but also in the social and environmental categories [44,45]. A direct consequence of the implementation of SHRM is the development of sustainable human resources, i.e., highly qualified employee who understand and follow the principles of sustainable development throughout the course of their work [46-48].

SHRM is a new approach to the realization of personnel function, which aims at the integration of potentially contradictory economic, ecological and social goals. The SHRM model consists of three components: economic HRM, green HRM and SRHRM [45]. SRHRM is one of the key components of SHRM. Its essence is a socially-sensitive approach to human resources implemented by personnel practices within both HRM and CSR. De facto SRHRM pertains to CSR's internal dimension and fosters corporate social responsibility with a view to attaining environmental and social values by developing ethical attitudes based on honesty and trust in employees. Thus, the concept of SRHRM provides conditions promoting sustainable development.

Despite a marked increase in the studies and practices regarding both sustainable development and HRM and CSR, analyses of the correlations between the fields conducted to date have been sparse [37]. Above all, there is a small number of publications on SRHRM implementation in the context of sustainable organization-building in Poland. A review of the Polish source literature revealed a gap with respect to empirical studies in the field of the relationships between SRHRM and sustainable development. What is more, there has been no attempt to assess the relationship between SRHRM 
practices and the sustainable development of Polish organizations, which provided the author with an impulse to undertake research in the field.

The objective of the study is to diagnose the activity of young enterprises operating across Poland in the field of SRHRM oriented at developing good relations with the primary group of stakeholders, which includes employees, and to carry out an evaluation of the effect of SRHRM practices on sustainable development of organizations. The analysis includes an identification of SRHRM practices embraced by organizations and their prioritization in accordance with their effect on the sustainable development of organizations. The main research problem was to establish correlation between the assessment of the relation of SRHRM practices with the sustainable development of organizations and their practical implementation.

In the course of analyses, the following research questions were addressed:

-Which SRHRM practices are most often implemented in young Polish enterprises?

-Which SRHRM practices are key to the sustainable development of organizations in the Polish reality?

-Is there a correlation between the assessment of the relation of SRHRM practices with the sustainable development of organizations and its practical implementation in the young Polish enterprises analyzed?

In order to solve the above presented problems, the study was based on a review of literature, a diagnostic survey method, and statistical and comparative analyses.

The interest of the authors in Polish enterprises grows from the fact that usually modern methods in the field of management are implemented in Polish organizations with delay. That is why some practices, which in Western countries have been realized for years, are new in Poland. The authors intended to survey to what extend Polish enterprises have advanced in implementing SRHRM practices, which are the element of a new model of the personnel function evolution, that is SHRM. Finding the gap in the area of desired practice of HRM may, according to the authors, give impetus to improving this field of management in the future.

The first years of functioning of a young enterprise on the market are a test of its survival. That is why in this period of time managers very often concentrate on the realization of economic goals. Social aspects of performance, especially voluntary ones, are usually relegated to secondary status. The authors tried to inquire, whether, and if yes, how deeply, young Polish enterprises are familiar with the concept of SRHRM, and to what extent they are willing to realize this practice in the time of start-up. The authors believe that the scope of implementation of SRHRM is a kind of barometer of the level of CSR importance in the successful organization building.

The principal restriction encountered in the course of research was the shortage of studies conducted in the young enterprise population, which made it difficult to carry out a comparative analysis of the results of research. The reason behind this is that the results of published analyses are typically presented in the form of a profile of the number of entities expressed by the number of employed workers, and less often accounting for the time period of their operation on the market.

The article is composed of five sections. The introductory part presents the essence of the concept of sustainable development and its relation to CSR, which is the background of the study considerations. In addition, it presents the reasons for the growth of interest in SHRM and SRHRM. Further on, there is an outline of the research gap identified in source literature which prompted the author's motivation to carry out personal research. It includes a definition of the research objective, a brief overview of research problems, applied methods, study limitations, the composition of the article and its contribution to science.

In Section 2, the theoretical background of the considerations in question is presented in the context of the world's literature review. Here, the focus is on the determination of the role of human resources and human resource management in sustainable development and sustainable organization-building. 
Next, the nature of SRHRM and the benefits of its implementation are presented and the relationship between SRHRM and CSR is examined. Furthermore, there is a review of the SRHRM practices.

Section 3 outlines the subject matter of the research and the population studied, formulates research hypotheses and describes the methods employed. Thereafter, there is a discussion involving the research findings. It includes an assessment of the impact of SRHRM on the sustainable development of young organizations and a diagnosis of the scope of their implementation in the enterprises studied. Analysis of the research outcome was performed in the context of studies conducted by other authors. The final section demonstrates key conclusions, references to the extent of verification of research hypotheses and recommendations for future research directions.

This study shall contribute to source literature by diagnosing a gap associated with SRHRM use as a vehicle for increasing the sustainable development of organizations in the Polish reality. In the opinion of the study authors, research findings may stimulate interest in the implementation of the SRHRM concept in Polish organizations and in extending the scope of its application as an instrument for sustainable organization-building. This is particularly important in relation to young organizations' development since the implementation of socially responsible HRM practices during the early stage of development of an organization provides it with an opportunity to improve its sustainability performance.

\section{Literature Review}

\subsection{The Role of HRM in the Creation of Sustainable Organizations Development}

Continuing along the path of sustainable development is becoming a necessity given our rapidly deteriorating natural environment and the increase in social challenges. It is mostly expected from enterprises, as they grossly contribute to environmental degradation [46]. Enterprises choosing to base their operations on the triple-bottom line principle [49] are referred to as sustainable enterprises.

According to Grudzewski et al., sustainable enterprises are enterprises capable of ongoing development, adaptation, learning, revitalization and reorientation [50]. The purpose of sustainable enterprise activities is to achieve an economic, social and environmental balance [49]. Economic sustainability requires enterprise profitability to be increased by efficient resource use, effective undertakings, good management, planning and control. Environmental sustainability necessitates the prevention of adverse and irreversible consequences for the environment through efficient use of natural resources, soil and water protection, and skillful waste management. Social sustainability involves the obligation to respond to the needs of all company stakeholders $[3,51]$. As a result, the prospects of succeeding in the case of sustainable enterprises go far beyond the financial dimension. These are companies which not only yield economic profits, but also take care of the environment and contribute to the social balance. Enterprises following the sustainable development principle apply systems and processes which adhere to the principles of efficient use of natural energy and resources, low pollutant emissions, safety assurance, and satisfaction of employees, consumers and communities [52].

Such business entities would not exist without appropriate staff. The environmental and social conscience of workers, fostered by their activity and competencies, constitutes the foundation of effectiveness and efficiency of actions in the area of sustainable development [46]. Thus, more and more frequently attention is paid to the key role of human resources and HR management in the implementation of the idea of sustainable development. Many authors agree with the thesis that the HR function is a potent instrument of sustainable organization-building [34,53,54]. The group of researchers which explore the issue of the HRM role in the implementation of the strategy of sustainable development is constantly expanding. Source literature emphasizes that the objective of the human resource department is to support the organization on the road to sustainable development [37], whereas HRM practices are essential for attracting and retaining personnel who will strive to attain the goals of sustainable development $[37,38,55]$. 
Human resources play a crucial role in the creation of sustainable development culture $[38,56]$. This is because responsibility culture development starts with the HR function. HRM policies and strategies create a framework for sustainable development culture by raising employee awareness in the field. Most of all, it is underpinned that the HR function may facilitate CSR strategy development and implementation [57-62]. Appropriate personnel policy favors intensification of desirable sociallyand environmentally-oriented behaviours [56]. Therefore, it is emphasized that the HR function has a strategic role to play in CSR initiatives of organizations [63]. The role of the HR function in the development of sustainable enterprises is further expressed by the development of sustainable personnel. This term refers to highly qualified employees who understand and follow the principles of sustainable development at work [46].

For HRM to fulfill such a leading role, the HR function should be treated as a strategic partner participating in the policy of sustainable development. Needless to say, one of the main challenges for modern HRM is its fusion with the idea of sustainable development and its orientation at supporting aims related to economic, social and environmental equilibrium [64]. This is reflected in the SHRM concept.

According to Ehnert, SHRM means taking up such practices that allow organizations to attain goals in a long-term perspective and that at the same time reflect their great concern for their employees [65]. Kramar would broaden the definition to include the minimization of the negative effect of enterprise operations on the natural environment, employees and communities [42]. Cohen et al. [20] adds that sustainable human resources management promotes the strategy of sustainable development in organizations by:

- just treatment, commitment to employee development and welfare;

- building employee trust and increasing their motivation to work for the benefit of sustainable development;

- taking care of internal stakeholders' (employees) and external stakeholders' health;

- fostering environment-friendly practices.

Given the above, SHRM contributes not only to the attainment of economic goals but also to the achievement of a far-reaching balance between inter-generational needs, thus preventing serious future environmental or social problems [46,49]. The implementation of this concept involves the need to modify the HRM philosophy so as to include socioenvironmental objectives in all subareas of HRM, from employment planning, to recruitment, selection, employee motivation and development, to employee assessment and impact on the conditions of work. This implies recruiting sustainable employees, broadening employee knowledge about sustainability, encouraging employees to undertake socially and environmentally oriented actions [44] and reward them for the effects produced. Rather than performed occasionally, these practices should become a permanent element of the personnel strategy.

One crucial component of SHRM is SRHRM. It is a manifestation of a responsible and honest approach to employees, which preconditions the use of their knowledge and stimulation of their participation in pursuing the objectives of sustainable development.

\subsection{The Essence and Benefits of SRHRM Implementation}

A sustainable enterprise is the one which is concerned with satisfying the needs and interests of equal groups of stakeholders. This is because positive relations with the stakeholders reduce operation costs, minimize risks, increase knowledge capital and promote goodwill. In relation to an organization's success creation, employees are particularly vital stakeholders. Commitment to good relations with workers is of the utmost importance in these times of the knowledge economy, where the foundation for the creation of added value is the intellectual capital. Relations with employees are unique in nature given their sensitivity to ill-treatment. To develop effective relations, organizations need to show respect for the rights and personal dignity of the employed. However, despite the 
fact that human resources and their management are seen as critical in terms of an organizations' success [66], in practice the prevailing approach is that of HR exploitation [67]. The introduction of SRHRM favors counteracting this negative tendency.

SRHRM is a concept which derives from and is strongly correlated with CSR. Authors tackling the issue indicate that there is a feedback loop between the two fields [68-78]. While CSR has an impact on HR, HRM has a key role to play in CSR implementation [56,73]. Relations between CSR and HRM in available literature usually fall under two broad categories [68,79,80]:

-CSR supported by HRM (HRM practices used to involve employees in CSR implementation); -HRM supported by CSR (CSR practices used to attract, keep and motivate employees).

SRHRM is a concept founded upon the integration of both domains and accounting for the two-way CSR-HRM relation [72,81]. SRHRM comprises a socially-conscious approach to human resources implemented by personnel practices within both HRM and CSR [82]. They are a means by which HRM effectiveness is increased by incorporating employees' needs into the needs of organizations, which leads to greater involvement and satisfaction. On the other hand, given that SRHRM pertains to CSR's internal dimension, it can foster corporate social responsibility with a view to attaining environmental and social values by developing ethical attitudes based on honesty and trust in employees. SRHRM as a social dimension of SHRM is consistent with broadly understood corporate social responsibility oriented at the optimum use of employee potential with simultaneous respect for their rights and needs. The said dimension of HRM is manifested by an employee-centred approach according to which employees are treated as crucial stakeholders [45]. SRHRM can be seen in, amongst other things, voluntary non-business actions aimed at meeting long-term employee needs, ensuring job satisfaction and development opportunities [83]. The principle of SRHRM is to engage in an active dialogue with employees. This fosters trust capital development. Trust is a crucial element of cooperation. It promotes and maintains it, encourages information exchange, enriches relations, prompts growth in candor and mutual acceptance, and aids conflict resolution [84].

Practical implementation of the trust-based SRHRM is manifested by an observation of ethical principles in relations with employees throughout all stages of the personnel process (from recruitment and selection to motivation, assessment and development, to employment restructuring). Table 1 shows a selection of SRHRM practices.

Table 1. Selected SRHRM practices.

\begin{tabular}{|c|c|}
\hline Area & Examples of Practices \\
\hline $\begin{array}{l}\text { Employee selection } \\
\text { (recruitment, selection, adaptation) }\end{array}$ & $\begin{array}{l}\text {-honest, non-discriminating job offers } \\
\text { - ethical job interview } \\
\text {-implementation of the "candidate experience" concept } \\
\text { - friendly employee adaptation }\end{array}$ \\
\hline Employee motivation & $\begin{array}{l}\text { - generous remuneration } \\
\text { - transparent and objective criteria of gratification } \\
\text {-timely payment of remunerations } \\
\text { —comprehensive social package (extra insurance, healthcare, pension plans) } \\
\text { —employee participation in management }\end{array}$ \\
\hline Employee assessment & $\begin{array}{l}\text { — transparency of the system of period performance appraisals } \\
\text { —objectivity of evaluation criteria } \\
\text { — elimination of errors in the process of periodic appraisals } \\
\text { — conduct of constructive assessment interviews }\end{array}$ \\
\hline Employee development & $\begin{array}{l}\text { —investment in employee development } \\
\text { —assurance of equal access to training } \\
\text { — employee development support (mentoring, coaching) } \\
\text { — counseling and support with respect to professional career management }\end{array}$ \\
\hline
\end{tabular}


Table 1. Cont.

\begin{tabular}{|c|c|}
\hline Area & Examples of Practices \\
\hline Health prophylaxis and work safety & 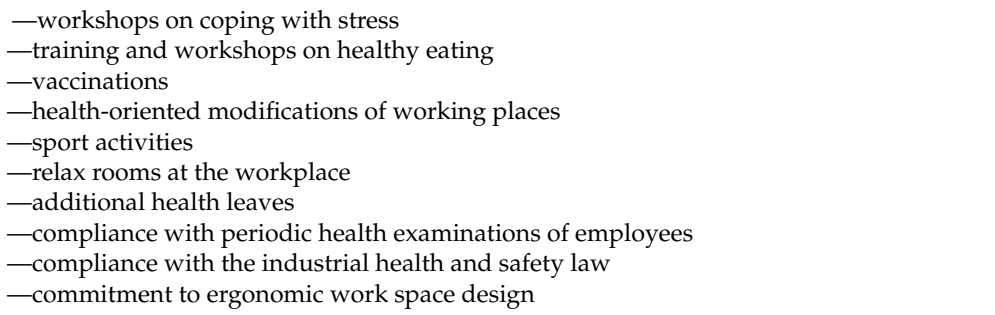 \\
\hline Diversity Management & $\begin{array}{l}\text {-integration programmes } \\
\text { - equal opportunities programmes } \\
\text {-improvements for persons with disabilities } \\
\text { - multicultural teams } \\
\text { - work-life balance programmes (nonstandard forms of employment, improvements for } \\
\text { parents, additional parental leaves) }\end{array}$ \\
\hline Employment restructuring & $\begin{array}{l}\text { - dismissal having regard to the values of respect for human dignity and employee rights } \\
\text {-just and clear disciplinary procedures } \\
\text { —outplacement }\end{array}$ \\
\hline
\end{tabular}

Socially responsible practices in the field of HRM generate a number of direct benefits. Most of all, they have a positive effect on internal and external employer branding. The reason behind this is that the most important factor affecting an organization's reputation as a workplace is the way in which it treats employees [80,85]. The research carried out among 100 most reputable firms in Spain showed that socially responsible practice implemented for employees, directly and positively influenced the reputation of the employer [86]. Subject literature emphasizes that a corporate social strategy may be employed in order to attract, maintain and motivate employees [68,73]. An increase in employee motivation and morale, on the other hand, has a positive impact on their involvement [87], productivity [88] and company loyalty, which in turn may improve financial results $[63,73]$. The application of socially responsible practices in the area of development, the development of working conditions and relations between humans may also contribute directly to a decrease in absences and personnel rotation [37]. More and more SRHRM practices seem to be indispensable to meeting economic and demographic challenges concerning personnel policy, such as the aging of society, the workforce shortage, or the talent war [65,73]. The implementation of the SRHRM concept may also become a panacea for increasing personnel fluctuation, a decrease in employee loyalty to their companies, an increase in levels of work stress, and falling employee satisfaction [31]. Even though this mode of applying the CSR perspective to HRM does not amend the HRM goals, it does contribute to their improved realization $[63,73]$ for it becomes a mechanism for unlocking the human capital, which is fundamental to the development of sustainable organizations and to their ability to gain a long-term competitive advantage $[56,89]$.

\section{Materials and Methods}

The subject matter of the research comprised SRHRM practices followed by young Polish enterprises. The list of activities included in the research is presented in Table 2. The diagnosis was conducted with reference to 35 activities implemented at various stages of the personnel process. The list of practices was identified pursuant to the analysis of source literature. 
Table 2. The list of SRHRM practices included in the research.

\begin{tabular}{|c|c|}
\hline Activity Number & Activities \\
\hline 1 & Commitment to fairness of one's employment offer \\
\hline 2 & $\begin{array}{l}\text { Commitment to non-discrimination of vacancy advertising, i.e., eliminating elements which could } \\
\text { discriminate because of sex, age, appearance, disability, etc. }\end{array}$ \\
\hline 3 & Employing persons with disabilities \\
\hline 4 & Employing people from the age group of 50 and above \\
\hline 5 & $\begin{array}{l}\text { Commitment to good relations with candidates who have not been employed } \\
\text { (candidate experience) }\end{array}$ \\
\hline 6 & Facilitating new employee adaptation \\
\hline 7 & Transparent system of periodic performance appraisals \\
\hline 8 & Investing in employee development \\
\hline 9 & Commitment to equal access to employee training \\
\hline 10 & $\begin{array}{l}\text { Supporting employees who are made redundant (helping to find accommodation, } \\
\text { psychological support) }\end{array}$ \\
\hline 11 & Compliance with the industrial health and safety law \\
\hline 12 & Providing generous remuneration \\
\hline 11 & Transparent rules of remuneration \\
\hline 14 & Comprehensive social benefits \\
\hline 15 & Applying solutions facilitating the attainment of a work-life balance (such as flexible working hours) \\
\hline 16 & Ability of employees to co-decide on matters relating to company operation (participation) \\
\hline 17 & Just and clear dismissal procedures \\
\hline 18 & Development and implementation of an ethical code \\
\hline 19 & Conduct of environmental audits \\
\hline 20 & Award of ethical certificates \\
\hline 21 & $\begin{array}{l}\text { Cooperating only with those business partners who are certified to be in compliance with } \\
\text { ethical requirements }\end{array}$ \\
\hline 22 & Implementing procedures for combating discrimination, mobbing and harassment at work \\
\hline 23 & Ethical Code training organization \\
\hline 24 & Organization of training sessions on combating discrimination, mobbing and harassment \\
\hline 25 & Promoting a healthy lifestyle and civilization disease prevention among employees \\
\hline 26 & Conducting health-oriented training and workshops (such as coping with stress, etc.) \\
\hline 27 & $\begin{array}{l}\text { Financial support for employees with respect to healthy lifestyles (such as money to buy sportswear, } \\
\text { sports equipment, gym or swimming-pool memberships, etc.) }\end{array}$ \\
\hline 28 & $\begin{array}{l}\text { Investment in infrastructure promoting a healthy lifestyle (such as bicycle parking stations, healthy } \\
\text { food canteens) }\end{array}$ \\
\hline 29 & $\begin{array}{l}\text { Employee involvement in social projects (aiding shelters, renovating preschools) as part of } \\
\text { corporate volunteering }\end{array}$ \\
\hline 30 & $\begin{array}{l}\text { Adjustment of working conditions to meet the needs of various employee groups (such as people } \\
\text { from the age group of } 50 \text { and above, the disabled) }\end{array}$ \\
\hline 31 & Inclusion of social goals of HRM in company strategy \\
\hline 32 & Measurement of effectiveness of environmental actions in HRM \\
\hline 33 & Provision for socially responsible HRM activities-related expenditure in the budget \\
\hline 34 & HRM socially responsible action progress monitoring \\
\hline 35 & Drafting reports on social responsibility in HRM \\
\hline
\end{tabular}

With a view to analyzing the effect of the above-listed socially responsible practices on the policy of sustainable development, a (partial) survey was conducted among a random, representative population of 150 young enterprises with their headquarters in Poland. Young enterprises were defined as those operating on the market for less than three years. The study was conducted in January 2018 with the application of the CATI technique [90]. The study sample was selected on a layer basis. 
First, 25 entities from each of the six Polish regions were drawn: Central, South, East, North-West, South-West and North. The survey targeted individuals in charge of HRM policy development in the analyzed enterprises. The characteristic features of the study population are shown in Table 3.

Table 3. Details of young enterprises included in the study.

\begin{tabular}{|c|c|c|}
\hline Criterion & Number of Enterprises & Percentage \\
\hline \multicolumn{3}{|l|}{ Time on the market: } \\
\hline up to 1 year & 14 & 9.3 \\
\hline $1-3$ years & 136 & 90.7 \\
\hline \multicolumn{3}{|l|}{ Employment number: } \\
\hline 50-249 employees & 100 & 66.7 \\
\hline 250-499 employees & 42 & 28.0 \\
\hline More than 500 employees & 8 & 5.3 \\
\hline \multicolumn{3}{|l|}{ Main type of activity: } \\
\hline production & 43 & 28.7 \\
\hline services & 99 & 66.0 \\
\hline trade & 8 & 5.3 \\
\hline \multicolumn{3}{|l|}{ Scope of operations } \\
\hline local & 37 & 24.7 \\
\hline regional & 20 & 13.3 \\
\hline national & 44 & 29.3 \\
\hline international & 49 & 32.7 \\
\hline \multicolumn{3}{|l|}{ Respondent's position: } \\
\hline HR Director & 8 & 5.3 \\
\hline Head of HR Department & 126 & 84.0 \\
\hline CEO & 12 & 8.0 \\
\hline other & 4 & 2.7 \\
\hline
\end{tabular}

The enterprises which prevailed in the population studied were those operating on the market for more than one year. They accounted for as much as $90.7 \%$ of the study population. The size of the companies which dominated the population studied was medium, i.e., employing between 50 and 249 employees. Their percentage was established at $66.7 \%$. The prevailing type of business activity of the study entities was provision of services (66\%). In terms of the type of ownership, the largest group was that of limited liability companies, which constituted $57.3 \%$ of the study group. Next, with respect to the scope of operations, the dominant enterprises were domestic enterprises (29.3\%). Respondents were mainly heads of human resource departments (84\%).

One of the most important criterion of the surveyed enterprises choice was their size measured with the number of employees. In our research we concentrated on medium and large companies, which-as it has been proven in other research-are more interested in CSR initiatives implementation than small firms [91] and also have better qualified managers [92]. It is worth noticing that this criterion is not very often used in analysis, which is confirmed by the results of the Dang and Li's research [93]. These authors analyzed 100 empirical papers from top finance, accounting, and economics journals and ascertained that the most popular firm size proxies in empirical corporate finance research are total assets, sales, and market value of equity. However, they believe that size is a firm fundamental variable, any small difference may have critical impact on the dependant variable and other independent variables in empirical study. Besides, great caution must be exercised when some variables are collinear with the different firm size measures. They also underline that the choice of company size depends on the concrete goal of research [93].

Other important criterion in our research was the period of time when a company was functioning on the market, which allowed us to determine a group of young enterprises. The justification of this criterion choice was the possibility of obtaining data concerning the scale of SRHRM implementation 
in the first phase of the life cycle of the surveyed organizations. The results may, on the one hand, fill in the diagnosed in the literature gap, and, on the other hand, create the ground for further analysis giving the possibility to compare in the future the scope of the SRHRM implementation in young and mature companies.

Research allows the following:

- Acknowledgement of the Polish managers' opinions concerning the meaning of particular socially responsible human resource practices in shaping sustainable development of young enterprises

- Identification of practices which are key to sustainable enterprise-building in the opinion of Polish managers;

- Diagnosis of practices which in the opinions of respondents have a marginal role to play in sustainable enterprise-building;

- Determination of the frequency of implementation of individual socially responsible activities in the field of human resource management within the studied enterprises;

- Identification of practices most popular under Polish conditions;

- Diagnosis of practices which are rarely implemented by young enterprises under Polish conditions;

- Analysis of the correlation between the assessment of the relation of SRHRM practices with the sustainable development of organizations and their practical implementation in young Polish enterprises;

- Description of the above-mentioned correlation with the application of a mathematical model and a calculation of standard errors of the estimates.

Over the course of research, attempts were made to verify the following research hypotheses:

Hypothesis 1. Socially responsible activities declared by Polish managers in the area of HRM have an irregular relation with the sustainable development of young organizations.

Hypothesis 2. There is correlation between the assessment of the relation of SRHRM practices with the sustainable development of organizations and their implementation in young enterprises.

To verify Hypothesis 1, measures of central tendency, both classic and location (in the case of impact asymmetry), measures of dispersion, i.e., the extent to which a distribution is scattered, and measures of dispersion, demonstrating the mean deviation of individual activities from the average and the force of activity variability, were applied. The measures of asymmetry allowed determination of the force and the direction of asymmetry of assessment of individual SRHRM activities; whereas the measures of concentration let us analyze the spread of activity assessment round their mean value.

In the process of verification of Hypothesis 2, Spearman's rank correlation coefficient was used, which allowed the authors to determine the strength and direction of correlations between the impact of SRHRM activities on the sustainable development of young companies, and their practical implementation. Furthermore, the parameters of the linear regression model were estimated, which allowed the modelling of the relationship between the studied variables.

All of the above permitted an assessment of the extent of SRHRM concept implementation under Polish conditions in the context of supporting the sustainable development policy within young organizations.

\section{Results and Discussion}

\subsection{Assessment of the Relationship between SRHRM Practices and the Sustainable Development of Young Organizations}

The assessment of the relationship between SRHRM practices and the sustainable development of young organizations was conducted with the application of a five-level Likert scale, where 1 signified a very low relation and 5 a very strong relation of a given practice. To analyze the relation, the structure 
of the group was described by the calculation of measures of central tendency, both classic and location (in the case of impact asymmetry), measures of dispersion, specifying the extent to which a distribution is scattered, and measures of asymmetry and concentration (Table 4).

Table 4. Evaluation of the relationship between SRHRM practices and the sustainable development of organizations *.

\begin{tabular}{|c|c|c|c|c|c|c|c|c|}
\hline Activity No. & Total (Points) & $\begin{array}{l}\text { The Average } \\
\text { Strength of the } \\
\text { Relation (Points) }\end{array}$ & $\begin{array}{c}\text { Mode } \\
\text { (Points) }\end{array}$ & $\begin{array}{l}\text { Median } \\
\text { (Points) }\end{array}$ & $\begin{array}{c}\text { Standard } \\
\text { Deviation } \\
\text { (Points) }\end{array}$ & $\begin{array}{l}\text { Coefficient of } \\
\text { Variation } \\
\text { (Points) }\end{array}$ & $\begin{array}{l}\text { Strength of } \\
\text { Asymmetry } \\
\text { (Points) }\end{array}$ & $\begin{array}{c}\text { Kurtosis } \\
\text { (Points) }\end{array}$ \\
\hline 11 & 725 & 4.83 & 5 & 5 & 0.424 & 8.78 & -0.39 & 6.24 \\
\hline 2 & 690 & 4.6 & 5 & 5 & 0.835 & 18.16 & -0.48 & 6.12 \\
\hline 6 & 672 & 4.48 & 5 & 5 & 0.739 & 16.50 & -0.70 & 5.13 \\
\hline 13 & 667 & 4.45 & 5 & 5 & 0.710 & 15.96 & -0.78 & 2.66 \\
\hline 1 & 654 & 4.36 & 5 & 5 & 0.813 & 18.65 & -0.79 & 2.99 \\
\hline 9 & 649 & 4.33 & 5 & 5 & 0.901 & 20.83 & -0.75 & 2.92 \\
\hline 8 & 646 & 4.31 & 5 & 4 & 0.835 & 19.39 & -0.83 & 2.47 \\
\hline 12 & 643 & 4.29 & 5 & 4 & 0.814 & 18.98 & -0.88 & 0.63 \\
\hline 17 & 617 & 4.11 & 5 & 4 & 1.053 & 25.59 & -0.84 & 1.47 \\
\hline 14 & 604 & 4.03 & 5 & 4 & 1.080 & 26.83 & -0.90 & 0.83 \\
\hline 22 & 593 & 3.95 & 5 & 4 & 1.200 & 30.36 & -0.87 & 0.50 \\
\hline 7 & 583 & 3.89 & 5 & 4 & 1.207 & 31.06 & -0.92 & 0.23 \\
\hline 4 & 568 & 3.79 & 5 & 4 & 1.097 & 28.96 & -1.11 & -0.11 \\
\hline 18 & 561 & 3.74 & 5 & 4 & 1.353 & 36.18 & -0.93 & -0.50 \\
\hline 3 & 553 & 3.69 & 5 & 4 & 1.221 & 33.13 & -1.08 & -0.37 \\
\hline 5 & 546 & 3.64 & 4 & 4 & 1.166 & 32.03 & -0.309 & -0.17 \\
\hline 30 & 535 & 3.57 & 3 & 4 & 1.228 & 34.44 & 0.46 & -0.53 \\
\hline 31 & 531 & 3.54 & 3 & 4 & 1.145 & 32.34 & 0.47 & 0.03 \\
\hline 16 & 518 & 3.45 & 3 & 3 & 1.267 & 36.69 & 0.36 & -0.70 \\
\hline 15 & 500 & 3.33 & 3 & 3 & 1.278 & 38.34 & 0.26 & -0.62 \\
\hline 25 & 495 & 3.30 & 3 & 3 & 1.309 & 39.68 & 0.23 & -0.72 \\
\hline 24 & 460 & 3.07 & 3 & 3 & 1.299 & 42.35 & 0.05 & -0.86 \\
\hline 27 & 459 & 3.06 & 3 & 3 & 1.352 & 44.19 & 0.04 & -0.96 \\
\hline 28 & 451 & 3.01 & 3 & 3 & 1.363 & 45.35 & 0.00 & -1.04 \\
\hline 26 & 443 & 2.95 & 3 & 3 & 1.372 & 46.47 & -0.03 & -1.06 \\
\hline 19 & 439 & 2.93 & 3 & 3 & 1.296 & 44.28 & -0.06 & -0.84 \\
\hline 33 & 438 & 2.92 & 3 & 3 & 1.282 & 43.92 & -0.06 & -0.84 \\
\hline 23 & 432 & 2.88 & 3 & 3 & 1.295 & 44.96 & -0.09 & -0.97 \\
\hline 34 & 425 & 2.83 & 3 & 3 & 1.255 & 44.31 & -0.13 & -0.82 \\
\hline 29 & 423 & 2.82 & 3 & 3 & 1.336 & 47.39 & -0.13 & -1.03 \\
\hline 32 & 417 & 2.78 & 3 & 3 & 1.268 & 45.63 & -0.17 & -0.85 \\
\hline 10 & 416 & 2.77 & 3 & 3 & 1.275 & 45.98 & -0.18 & -0.86 \\
\hline 35 & 405 & 2.70 & 3 & 3 & 1.225 & 45.36 & -0.24 & -0.87 \\
\hline 20 & 362 & 2.41 & 3 & 3 & 1.275 & 52.85 & -0.46 & -0.92 \\
\hline 21 & 360 & 2.40 & 3 & 3 & 1.221 & 50.86 & -0.49 & -0.93 \\
\hline
\end{tabular}

To identify socially responsible HRM practices which, according to respondents, had a strong relation with the sustainable development of organizations, the study sample was divided into quartiles. The first quartile was composed of SRHRM activities of primordial importance for the sustainable development of organizations in the opinion of Polish managers. The third quartile, on the other hand, consisted of activities which did not contribute significantly to sustainable development-building.

The analyses demonstrated that it was compliant with the industrial health and safety law (activity no. 11), which had the greatest relation with the sustainable development of young enterprises. The point here is a special care of health and safety at work and not only minimal compliance with the regulations defined in the labor law. This approach is named as sustainable HRM practice also by other authors [94]. Most frequently, respondents evaluated its relation as being very high (mode and median 5) and the average strength of the relation of this activity was 4.83. Another practice deemed crucial within SRHRM was company commitment to nondiscrimination of vacancy advertising, 
i.e., eliminating elements which could discriminate because of sex, age, appearance, disability, etc. (activity no. 2). The relation of the above activity was most often assessed as very high, with an average rating of 4.6. Other activities the respondents identified as crucial were: facilitating new employee adaptation (activity no. 6) and transparent rules of remuneration (activity no. 13). The average strength of the relation of these activities was 4.48 and 4.45 , correspondingly, while the strength of variation of the relation extended from $16.5 \%$ to $15.9 \%$. Furthermore, the following activities were considered important for the sustainable development of organizations:

- commitment to fairness of one's employment offer (activity no. 1), with an impact average of 4.36; - equal access to training (activity no. 9), with an impact average of 4.33;

-investment in employee development (activity no. 8), with an impact average of 4.31;

- provision of generous remuneration (activity no. 12), with an impact average of 4.29;

- just and clear dismissal procedures (activity no. 17), with an impact average of 4.11.

With respect to the above-listed activities, the mode observed was at the level of 5, whereas the (relation diversity) - between 18.65 and 25.59.

Most managers opined that the SRHRM activity considered as having the weakest relation with the sustainable development of enterprises was cooperating only with those business partners who were certified to be in compliance with ethical requirements (activity no. 21). The mean impact of this activity was assessed at 2.41. An equally insignificant activity was the impact of an award of ethical certificates (activity no. 20). In the opinion of the respondents, the average relation of this practice with sustainable development was 2.40. There were also other activities that were seen as having a low relation.

—drafting reports on social responsibility in HRM (activity no. 35);

- support for dismissed employees (activity no. 10);

-measurement of effectiveness of environmental actions in HRM (activity no. 32);

-employee involvement in social projects as part of corporate volunteering (activity no. 29);

-HRM socially responsible action progress monitoring (activity no. 34);

- provision for socially responsible HRM activities-related expenditure in the budget (activity no. 23); —ethical code training organization (activity no. 33).

The effect of the above activities was deemed to be average, oscillating around 2.70 and 2.92 . The coefficient of variation of the strength of relationship of the activities in the last quartile, regarded as less vital for company development, was much higher than the coefficient of variation in the first quartile. It oscillated around $43 \%$ to $53 \%$, which signifies strong dispersion.

Given the average assessment of the relation of all SRHRM practices, which was 3.5 in the 5-level scale, we can affirm the following conclusion: the importance of SRHRM practices as instruments of support of sustainable development of organizations is appreciated by the studied entities. Nonetheless, some depreciation of the importance of activities associated with the implementation of procedural activities is evident. The managers covered by the research clearly chose to belittle the importance of practices such as:

-HRM socially responsible action progress monitoring;

—drafting reports on social responsibility in HRM;

-measurement of effectiveness of environmental actions in HRM; and

— provision for socially responsible HRM activities-related expenditure in the budget.

In the light of the fact that contractual partners' commitment to ethical principles was considered-according to our findings - an activity that was the least important of all, it may be assumed that the relevant entities have not yet fully developed a culture of responsibility, which guarantees an authentic social involvement of enterprises. Needless to say, the implementation 
of SRHRM practices should be a direct result of the canon of values, rules, and norms of conduct respected and followed by a given company. It would be difficult to discuss the effective and comprehensive implementation of the SRHRM concept in the absence of an appreciation of the above practices. Some interesting conclusions in this respect may be drawn from the analysis of the scope of SRHRM concept implementation under Polish conditions conducted in the subsequent part of the study.

\subsection{Evaluation of the Scope of SRHRM Concept Implementation in Polish Enterprises}

On the basis of data regarding the number of enterprises pursuing individual SRHRM practices, characteristics of their structures were developed. The data analysis covered the following statistical parameters: measures of location, dispersion, asymmetry and concentration. The mean number of enterprises pursuing a SRHRM activity was 97; the standard deviation of the number of enterprises implementing social activities from their mean value was by 39 companies. Half of the activities were accomplished by 105 enterprises at most, whereas another half-in no less than 105 entities. The range of the number of enterprises pursuing an activity was 126 (activity no. 11 was implemented by as many as 149 enterprises, whereas activity no. 21 by 23 companies only). The coefficient of variation of $39.97 \%$ indicates a moderate strength of differentiation in the number of enterprises implementing social activities. Approximately $67 \%$ of social activities were accomplished by 58 to 136 young enterprises. The left side asymmetry is indicative of the fact that the mean number of enterprises pursuing SRHRM activities (97) was understated in relation to the median value (central value). The structure index (the frequency of activities) oscillated between 15.3\% and 99.3\% (Table 5). We ought to emphasize that $63 \%$ of SRHRM practices were pursued in over $50 \%$ of young enterprises. This means that a few activities were conducted more rarely than others.

Table 5. Implementation of SRHRM practices in young Polish enterprises.

\begin{tabular}{ccc}
\hline Activity No. & $\begin{array}{c}\text { Number of Young Enterprises } \\
\text { Performing the Activity }\end{array}$ & $\begin{array}{c}\text { Percentage of Young Enterprises } \\
\text { Performing the Activity (\%) }\end{array}$ \\
\hline 1 & 147 & 98.00 \\
\hline 2 & 143 & 95.33 \\
\hline 3 & 113 & 75.33 \\
\hline 4 & 129 & 86.00 \\
\hline 5 & 119 & 79.33 \\
\hline 6 & 146 & 97.33 \\
\hline 7 & 120 & 80.00 \\
\hline 8 & 142 & 94.67 \\
\hline 9 & 142 & 94.67 \\
\hline 10 & 47 & 31.33 \\
\hline 11 & 149 & 99.33 \\
\hline 12 & 141 & 94.00 \\
\hline 13 & 147 & 98.00 \\
\hline 14 & 130 & 86.67 \\
\hline 15 & 96 & 64.00 \\
\hline 16 & 112 & 74.67 \\
\hline 17 & 130 & 86.67 \\
\hline 18 & 105 & 70.00 \\
\hline
\end{tabular}


Table 5. Cont.

\begin{tabular}{ccc}
\hline Activity No. & $\begin{array}{c}\text { Number of Young Enterprises } \\
\text { Performing the Activity }\end{array}$ & $\begin{array}{c}\text { Percentage of Young Enterprises } \\
\text { Performing the Activity (\%) }\end{array}$ \\
\hline 19 & 50 & 33.33 \\
\hline 20 & 25 & 16.67 \\
\hline 21 & 23 & 15.33 \\
\hline 22 & 119 & 79.33 \\
\hline 23 & 62 & 41.33 \\
\hline 24 & 77 & 51.33 \\
\hline 25 & 86 & 57.33 \\
\hline 26 & 68 & 45.33 \\
\hline 27 & 71 & 47.33 \\
\hline 28 & 64 & 42.67 \\
\hline 29 & 56 & 37.33 \\
\hline 30 & 97 & 64.67 \\
\hline 31 & 106 & 70.67 \\
\hline 32 & 56 & 37.33 \\
\hline 33 & 66 & 44.00 \\
\hline 34 & 62 & 41.33 \\
\hline 35 & 49 & 32.67 \\
\hline
\end{tabular}

Among the SRHRM practices most frequently implemented by the studied entities, the following should be listed:

- Activity no. 11, i.e., Compliance with industrial health and safety, was implemented by the greatest number of entities: 149 (99.33\% of the total)

- Activity no. 1, i.e., Commitment to fairness of one's employment offer and activity no. 13, i.e., Transparent rules of remuneration, accomplished by 147 enterprises ( $98 \%$ of the total);

- Activity no. 6, i.e., Facilitating new employee adaptation, implemented by 146 companies (97.33\% of the total);

- Activity no. 2, i.e., Commitment to nondiscrimination in vacancy advertising, i.e., Eliminating elements which could discriminate because of sex, age, appearance, disability, etc., declared by 143 companies ( $95.33 \%$ of the total);

- Activity no. 8, i.e., Investment in employee development, and activity no. 9, i.e., Equal access to training, pursued by 142 enterprises ( $94.67 \%$ total);

- Activity no. 12, i.e., Providing generous remuneration, implemented by 141 of the studied entities ( $94 \%$ of the total).

Analysis of the above data demonstrates that the analyzed entities quite frequently implement SRHRM practices. The findings show the widespread popularity of selected practices. This is further confirmed by other authors' research studies.

The study conducted by A. Pocztowski in the year 2013, which covered 50 Polish enterprises operating internationally, manifested that the studied entities were greatly involved with diversity management. The initiatives most often found in their company policies were: bullying prevention (64\% indications), anti-discriminatory activities $(52 \%)$, sexual harassment prevention $(32 \%)$, flexible working hours (32\%), accommodation for people with disabilities (30\%), age management (24\%) and ensuring work-life balance (18\%) [45]. Employers in Poland have adopted more and more serious 
approaches to the policy of diversity, as manifested by corporate practices, such as the organization of workshops on tolerance and the prevention of discrimination and participation in external projects, e.g. company presence at marches promoting equality [95].

On the other hand, in a survey conducted in December 2014 across the whole territory of Poland on a population of 850 entities, an activity which was implemented most often, and which fit within the framework of SRHRM practices, was investment in employee development, as declared by $30 \%$ of respondents [96]. Against the backdrop of original research presented herein, we can observe considerable progress in the field, for in the year 2018, investment in staff development was cited by as many as $96.7 \%$ of the 150 studied entities. This speaks of Polish entrepreneurs' growing awareness of the need to invest in human capital and to view this kind of expenditure not only in terms of cost but, above all, as a long-term investment.

Other research, conducted among 200 companies included in two rating lists: "Business Gazelles" and "Deloitte Technology Fast 50 in Central Europe" revealed that Polish employers pay considerable attention to the improvement of work conditions. The research demonstrated that $96 \%$ of enterprises have invested in industrial health and safety improvements, a reduction of the occupational disease risk, and/or an improvement of social conditions in the workplace over the course of the last three years. Eighty-three percent of the entities incorporated solutions aimed at improving the welfare of employees through the provision of healthcare packages, subsidized sports/recreational memberships and/or holidays. Seventy-seven percent introduced the work-life balance concept, and 60\% declared involvement in improving employees' qualifications through the implementation of various training methods (e-learning, coaching, and others) or by subsidizing external forms of education (such as post-graduate university courses) [97].

Our analysis of the presented study findings shows that the widespread presence of socially responsible practices within HRM is a growing trend in the Polish reality. It is a consequence of the fact that the CSR topic is gaining popularity in Poland, as evidenced by the rising number of social initiatives undertaken by employers [98]. According to annual reports concerning CSR published in Poland, Polish entrepreneurs' involvement in the implementation of socially responsible practices is growing $[95,99]$ and so is the use of social media in CSR. An analysis of the latest report on CSR issued in 2017 indicated that out of the 117 cited in the report, as many as 100 followed socially responsible work practices. The number of work-post-related practices nearly doubled compared to the preceding year. This trend may be justified by, most notably, employee market development in Poland. At the same time, the cited reports seem to confirm the hypothesis that the SRHRM concept is not implemented in a comprehensive manner in Poland. The majority of the studied entities pursue individual practices or several basic activities. The leader of the researched companies, Volkswagen Motor Poland, implemented 16 socially responsible work practices [95]. The lack of a comprehensive approach to SRHRM implementation is further demonstrated by the findings of research conducted by the authors of this study on a population of young enterprises.

Despite the positive growth trend with respect to SRHRM, original studies show that there are other, disturbing phenomena. First of all, it should be highlighted that practices listed as those most frequently implemented are of an obligatory nature, for entrepreneurs are obliged to follow them by law. These are activities, such as observance of the industrial health and safety law; commitment to non-discrimination in vacancy advertising and equal access to training. The Constitution of the Republic of Poland and the Labour Code prohibit any type of discrimination in employment, whether direct or indirect, in particular, due to sex, age, disability, race, religion, nationality, political belief, trade union membership, ethnic origin, denomination, and sexual orientation. Frequent implementation of obligatory practices may not necessarily be an indication of the implementation of the SRHRM concept in a given company as the essence of SRHRM is the voluntary adoption of socially responsible practices. Hence, it may be assumed that rather than SRHRM concept implementation, we may be dealing with PR-oriented CSR in some organizations. Obrad and Gherhes also highlight the likeliness of this risk [37]. According to them, it continues to be quite a 
frequent occurrence in the Romanian corporate environment. In Poland as well as in Romania, CSR is at times used solely as a marketing instrument [100]. Here, attention should be drawn to the risk incurred by adopting such an approach. A consequence of PR-oriented CSR is ignorance regarding employees' real needs and the employment of human resource practices only as a PR instrument used to manipulate society with a view to generating profit. Such actions are not reliable in the eyes of company stakeholders, whereas the benefits of their adoption may be apparent and short-term. Therefore, we need to emphasize that SRHRM concept's implementation may be considered comprehensive and authentic only when companies are truly committed to their employees, their safety and broadly understood physical and mental health, and when they provide optimum conditions for work and development.

Another negative symptom revealed during the research is the limited scope of the implementation of numerous human resource practices which are vital to SRHRM. Studies demonstrate that the least popular activity was exclusive cooperation with business partners who are certified in terms of compliance with ethical requirements (activity no. 21). This activity is practiced the least frequently - by only 23 of the studied enterprises (15.33\% of the group). Among other equally infrequent activities were:

- Activity no. 20 , i.e., The award of ethical certificates, implemented by a mere 25 entities $(16.67 \%$ of the population);

- Activity no. 10, i.e., Supporting employees who are made redundant (help with finding a new job, psychological support), declared by 47 enterprises (31.33\% of the group).

- Activity no. 35, i.e., Drafting reports on social responsibility in HRM, pursued by 49 companies (32.67\% of the population);

- Activity no. 19, i.e., The conduct of ethical audits, implemented by 50 entities $(33.33 \%$ of the population);

- Activity no. 32, i.e., Measurement of effectiveness of environmental actions in hrm; and activity no. 29 , i.e. Employee involvement in social projects as part of corporate volunteering, implemented by 56 enterprises (37.33\& of the group);

- Activity no. 34 , i.e., Hrm socially responsible action progress monitoring and activity no. 29 , i.e., Ethical code workshop organization, implemented by 62 enterprises ( $41.33 \%$ of the group).

The above-presented results point to the low popularity of activities associated with the implementation of SRHRM procedures by organizations, i.e., HRM socially responsible action progress monitoring, drafting reports on social responsibility in HRM, measurement of the effectiveness of socially responsible activities in HRM, and provision for socially responsible HRM activities-related expenditure in the budget. The comprehensive implementation of the SRHRM concept is impossible in the absence of the above-mentioned practices. It should be underlined that the lack of CSR practice implementation can be caused by a short period of the surveyed organizations functioning on the market. Especially that realizing some practices may take more time that three years.

We opine that a particularly important, scarce activity is the reporting of SRHRM practices which plays a vital role in the popularization of the SRHRM concept and, consequently, the scope of its practical application. For the reporting companies, in turn, this presents yet another opportunity to arrange, systematize and develop SRHRM practices. By bringing together all information regarding socially responsible HRM practices, it allows a broad view of the manner in which human resource policy is pursued from the point of view of its inclusion of the principles of sustainable development. Data included in such reports show not only where a given organization is, but also what it intends to achieve in the nearest future. Additionally, social reports facilitate an analysis of the effectiveness of conducted activities and their adoption to the needs of their stakeholders. Despite the above-specified benefits of reporting, the practice was pursued by a mere $32.67 \%$ of the entities in the studied group of young enterprises. 
The minor scale of CSR reporting has been confirmed by other research studies. In 2013, a study was carried out covering the top 100 companies listed in the "Rzeczpospolita" newspaper's ranking of Poland's 500 largest companies. The results of the analysis demonstrated that only 12 of those companies had drafted social reports [100]. In the interest of comparison, according to the British FTSE 100 , as many as $76 \%$ of all registered companies reported non-financial matters [101]. What is more, a study carried out in 2014 on a population of 300 Polish companies revealed that only one out of five enterprises had a CSR report prepared [102].

An analysis of the annual CSR reports in Poland shows that there is growing interest in social reporting. However, reporting non-financial data in Poland is still considered to be of marginal importance. One of the reasons behind Polish companies not going public about their social involvement is that such practices may be viewed as a source of risk in terms of competitive information publication [103].

The authors of the study opine that in the Polish reality it is still necessary not only to make the companies aware of the need for social reporting, including SRHRM reporting but also to extend such reporting by introducing a broader range of factors related to SRHRM practices. Under Polish conditions, the key elements of social reports made public by enterprises are environmental indicators (such as energy and water consumption, sewage and waste), data referring to responsibility owed towards the community (such as corruption, competitive behavior) and responsibility for products (such as consumers' health and safety, product marking, compliance with requirements). Data pertaining to SRHRM practices are significantly less prevalent. If they happen to be reported, they are usually limited to information concerning the conditions of work, training, and compliance with human rights (such as anti-discriminatory practices and work safety).

Given the foregoing, we may conclude that enterprises in Poland are characterized by a low level of maturity with respect to the implementation of the SRHRM concept. Original studies conducted on a group of young enterprises as well as studies carried out by other authors tend to confirm this.

In a study conducted in the year 2014 on 300 companies (consisting of 100 large and 200 small and medium enterprises), employee-oriented activities were declared by over $85 \%$ of entities. However, only half of the large companies (54\%) and every fifth enterprise from the SME sector (19\%) have implemented the CSR strategy. This indicated that the remaining entities conducted socially responsible activities on an ad hoc basis, if at all. What is more, only a small percentage of companies ( $31 \%$ large and 16\% SME) had the effects of their CSR activities assessed [102]. In comparison with the findings of our original research, it is fair to say that there have been no significant changes in this respect. Measuring the effectiveness of environmental actions in HRM continues to be a rare practice, declared a mere $37.33 \%$ of young entities. The reason behind this could be the fact that sustainable HRM is a relatively new concept which requires further analyses, above all with respect to defining indicators for measuring and reporting [103].

Jastrzęskka, in turn, draws our attention to the conditions that are characteristic of Poland and which have a slower impact than in other states' evolution of the CSR concept and, consequently, the rate of SRHRM implementation. She claims that in Poland there is an absence of strong social movements that stimulate the social participation of citizens, control the commercial sector or motivate social responsibility. Furthermore, a typical feature of Polish CSR is the lack of institutionalism, which can also be observed in the political sphere. This is evidenced, above all, by the absence of a superior governmental strategy referring to CSR development, the shortage of budgetary resources allocated to CSR development-related activities, and the assignment of participants to local governments pursuing various, dispersed EU-funded projects with respect to CSR [2]. Under such conditions, it is difficult to follow the worldwide CSR trends, and the SRHRM concept is, without a doubt, one of them.

Needless to say, the first signs of Polish public administration's involvement in CSR-related matters should be seen in positive terms. This is demonstrated by, among other things, the project named "Partnership for the Attainment of Sustainable Development Goals" initiated in 2017 by the 
Ministry for Enterprise and the Ministry for Technology to integrate representatives of different environments for the purpose of effective realization of objectives on sustainable development. The above initiative is bound to raise awareness across a broader audience in terms of sustainable development's objectives as adopted by the international community, their importance for individual social groups, and the need of cooperation in their effective application [104], which may contribute to an increase in the interest in a comprehensive SRHRM implementation. A vital role in the popularization of practices of the broadly understood CSR, binding since the year 2017, is also played by Directive 2014/95/EU of the European Parliament and of the Council. This is because the Directive obliges large undertakings to disclose statements containing information relating to environmental matters, social and employee-related matters, respect for human rights, anti-corruption and bribery matters, but also to relate these practices with company strategies, the risk entailed and key outcome indicators [105]. In the opinion of the authors of this study, the reporting obligation may become a catalyst for positive change in the field of SRHRM and a precursor to a strategic approach to social responsibility in HRM. Hopefully, this will also contribute to an increase in the number of initiatives in the field.

\subsection{The Correlation Between the Assessment of the Relation of SRHRM Practices with the Sustainable Development of Organizations and Their Realization in Young Enterprises}

Over the course of the original research, an attempt was made to examine the correlation between the assessment of the relation of SRHRM practices with the sustainable development of organizations and their practical implementation. With a view to establishing the strength and direction of the interdependence of the variables, the Spearman's rank correlation coefficient was calculated (Table 6).

Table 6. The correlation between the assessment of the relation of SRHRM practices with the sustainable development of organizations and their realization in young enterprises.

\begin{tabular}{|c|c|c|c|c|c|c|}
\hline Activity No. & $\begin{array}{l}\text { The Assessment of the } \\
\text { Strength of the Relation }{ }^{1} \\
\text { (Variable X) }\end{array}$ & $\begin{array}{c}\text { Activities Pursued in } \\
\text { Enterprises }^{2} \text { (Variable Y) }\end{array}$ & $\operatorname{Rank} X^{3}$ & $\operatorname{Rank} Y^{4}$ & Di Distance & $\begin{array}{c}\text { Square of } \\
\text { Distance di }{ }^{2}\end{array}$ \\
\hline 1 & 654 & 147 & 5 & 2 & 3 & 9 \\
\hline 2 & 690 & 143 & 2 & 5 & -3 & 9 \\
\hline 3 & 553 & 113 & 15 & 15 & 0 & 0 \\
\hline 4 & 568 & 129 & 13 & 11 & 2 & 4 \\
\hline 5 & 546 & 119 & 16 & 13 & 3 & 9 \\
\hline 6 & 672 & 146 & 3 & 4 & -1 & 1 \\
\hline 7 & 583 & 120 & 12 & 12 & 0 & 0 \\
\hline 8 & 646 & 142 & 7 & 6 & 1 & 1 \\
\hline 9 & 649 & 142 & 6 & 7 & -1 & 1 \\
\hline 10 & 416 & 47 & 32 & 33 & -1 & 1 \\
\hline 11 & 725 & 149 & 1 & 1 & 0 & 0 \\
\hline 12 & 643 & 141 & 8 & 8 & 0 & 0 \\
\hline 13 & 667 & 147 & 4 & 3 & 1 & 1 \\
\hline 14 & 604 & 130 & 10 & 9 & 1 & 1 \\
\hline 15 & 500 & 96 & 20 & 20 & 0 & 0 \\
\hline 16 & 518 & 112 & 19 & 16 & 3 & 9 \\
\hline 17 & 617 & 130 & 9 & 10 & -1 & 1 \\
\hline 18 & 561 & 105 & 14 & 18 & -4 & 16 \\
\hline 19 & 439 & 50 & 26 & 31 & -5 & 25 \\
\hline 20 & 362 & 25 & 34 & 34 & 0 & 0 \\
\hline 21 & 360 & 23 & 35 & 35 & 0 & 0 \\
\hline 22 & 593 & 119 & 11 & 14 & -3 & 9 \\
\hline 23 & 432 & 62 & 28 & 27 & 1 & 1 \\
\hline 24 & 460 & 77 & 22 & 22 & 0 & 0 \\
\hline
\end{tabular}


Table 6. Cont.

\begin{tabular}{|c|c|c|c|c|c|c|}
\hline Activity No. & $\begin{array}{l}\text { The Assessment of the } \\
\text { Strength of the Relation }{ }^{1} \\
\text { (Variable X) }\end{array}$ & $\begin{array}{c}\text { Activities Pursued in } \\
\text { Enterprises }^{2} \text { (Variable Y) }\end{array}$ & $\operatorname{Rank} X^{3}$ & Rank $Y^{4}$ & Di Distance & $\begin{array}{c}\text { Square of } \\
\text { Distance di }\end{array}$ \\
\hline 25 & 495 & 86 & 21 & 21 & 0 & 0 \\
\hline 26 & 443 & 68 & 25 & 24 & 1 & 1 \\
\hline 27 & 459 & 71 & 23 & 23 & 0 & 0 \\
\hline 30 & 535 & 97 & 17 & 19 & -2 & 4 \\
\hline 31 & 531 & 106 & 18 & 17 & 1 & 1 \\
\hline 32 & 417 & 56 & 31 & 30 & 1 & 1 \\
\hline 33 & 438 & 66 & 27 & 25 & 2 & 4 \\
\hline
\end{tabular}

$$
\mathrm{r}_{\mathrm{d}}=1-\left(6 \times 116 / 35 \times\left(35^{\wedge} 2-1\right)\right)=0.984
$$

The 0.984 rank correlation coefficient demonstrates a very strong correlation between the assessment of the relation between socially responsible practices and the sustainable development of organizations and their practical implementation in the studied enterprises. This indicated that the practices which are pursued are those which—in the opinion of the management-are vital to the policy of sustainable development, as expressed by the high rating of their relation.

To describe the correlations between the impact of the above-mentioned variables, we used regression analysis. Figure 1 represents a linear regression function type II, which specified the development of correlations between the realization of SRHRM practices under the influence of changes in the rating of their assessment of the relation of SRHRM practices with the sustainable development of organizations in the study sample.

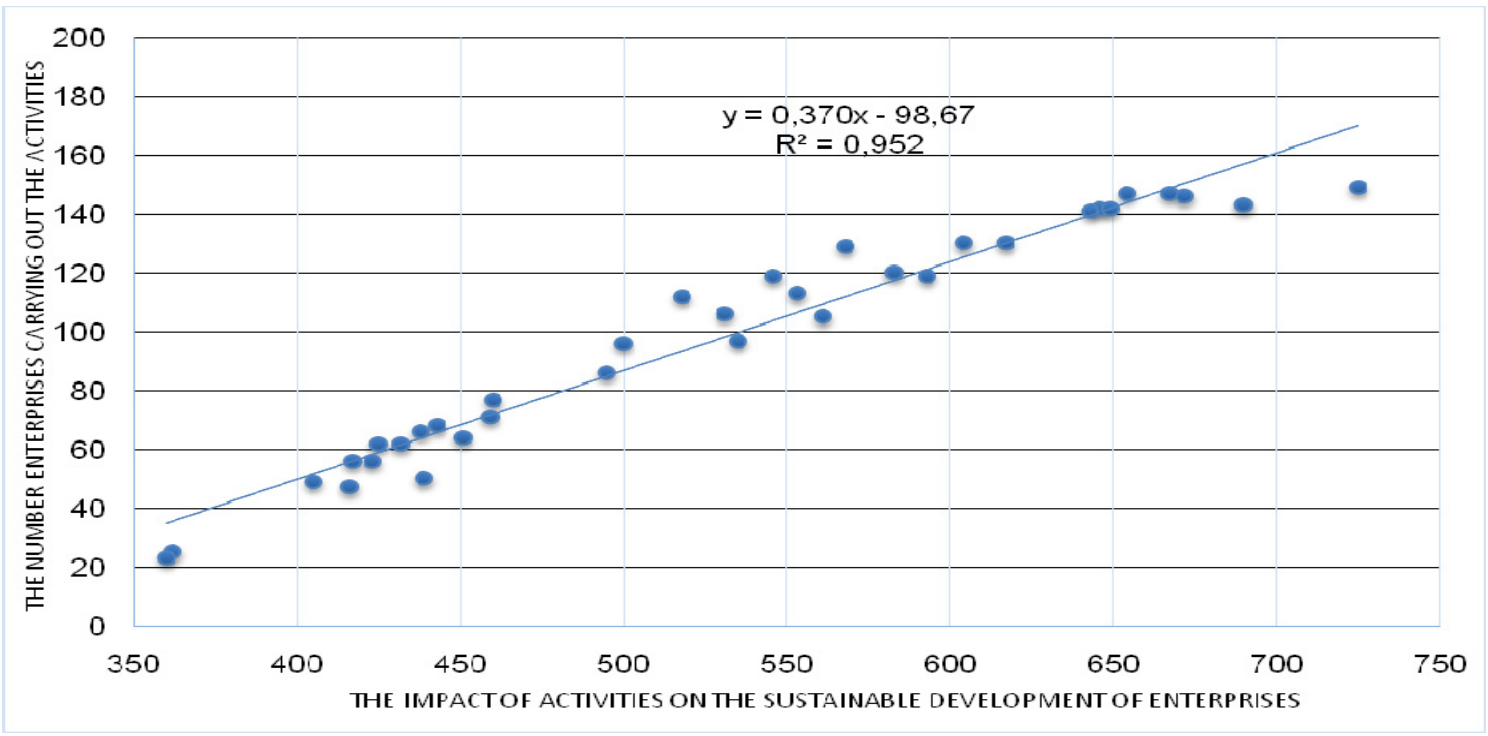

Figure 1. Correlation between the assessment of the relation of SRHRM practices with the sustainable development of organizations and their implementation in young Polish enterprises. 
The resultant regression coefficient $\mathrm{a}_{\mathrm{y}}=0.3706$ tells us that, in the study population, a 1-point impact growth in the assessment of the relation of SRHRM practices with the sustainable development of organizations results in an average increase of its realization by 0.3706 . The coefficient of determination $\mathrm{R}^{2}=0.9529$ determines that in $95.29 \%$ the changeability of the number of enterprises pursuing socially responsible HRM practices was explained by the estimated regression function (through the variability of the effect of activities on the sustainable development of young companies). Next, the coefficient of linear indetermination $(1-0.9529=0.0471=4.71 \%)$ yields information that in the studied sample of enterprises, the mere $4.7 \%$ changeability in the number of companies realizing social activity was not explained by the variability of the impact of activities on the sustainable development of enterprises.

The above-described regression function type II is a proxy variable of the function describing the studied relationship in all young enterprises in Poland. In the case of concluding with respect to unknown parameters of equations on the basis of data from the sample, a standard error of estimate of the regression coefficient $S_{a}$, a standard error of estimate of the polynomial $S_{b}$, and residual standard deviation $S_{z}$ were calculated. The linear regression model is represented by the following equation:

$$
\begin{gathered}
\mathrm{y}_{\mathrm{i}}=0.3706 \times \mathrm{x}_{\mathrm{i}}-98.678+\mathrm{z}_{\mathrm{yi}} \\
{\left[\mathrm{S}_{\mathrm{ay}}=0.014\right] \quad\left[\mathrm{S}_{\text {by }}=7.708\right] \quad\left[\mathrm{S}_{\mathrm{zy}}=8.54\right]}
\end{gathered}
$$

The standard error of estimate of the regression coefficient $S_{a}$ informs us that when estimating the regression coefficient in a population of generally young companies on the basis of the regression equation we may err by 0.014 . The standard error of estimate of the polynomial $\mathrm{S}_{\mathrm{b}}$ informs us that when estimating the polynomial, we may go wrong by 7.708, whereas the residual standard deviation $S_{z}$ informs us that the real value of the dependent variable differs by 8.54 from its theoretical value computed on the basis of the equation. The following hypotheses were made when drawing conclusions about the regression to the whole body of young enterprises:

$$
\begin{array}{ll}
\mathrm{H}_{0}: \alpha_{\mathrm{y}}=0 & \mathrm{H}_{0}: \beta_{\mathrm{y}}=0 \\
\mathrm{H}_{1}: \alpha_{\mathrm{y}} \neq 0 & \mathrm{H}_{1}: \beta_{\mathrm{y}} \neq 0
\end{array}
$$

The zero hypotheses presumed that the regression coefficient $\alpha_{\mathrm{y}}$ and the polynomial $\beta_{\mathrm{y}}$ in the population were statistically insignificant; while the alternative hypotheses assumed that the specified parameters were statistically significant. To verify the validity of assumptions stated in $\mathrm{H}_{0}$ the $\mathrm{t}$-Student statistics was employed.

$$
\mathrm{t}=\mathrm{a}_{\mathrm{y}} / \mathrm{S}_{\text {ay }} ; \quad \mathrm{t}=0.3706 / 0.014=26.471 ; \mathrm{t}=\mathrm{b}_{\mathrm{y}} / \mathrm{S}_{\mathrm{by}} ; \quad \mathrm{t}=-98.678 / 7.708=-12.802 ;
$$

The critical area is marked by the relation $\mathrm{P}\left(|\mathrm{t}| \geq \mathrm{t}_{\alpha ; \mathrm{s}}\right)=\alpha$ assuming the level of confidence to be $\alpha=0.05$ and the degrees of freedom $\mathrm{s}=\mathrm{n}-2$, the result obtained was $\mathrm{t}=2.037$. When comparing the computed test values with the critical value, it was demonstrated that the parameters $\alpha_{\mathrm{y}}$, $P(26.471>2.037)=0.05$, and $\beta_{y}, P(12.802>2.037)=0.05$ are statistically significant. This shows that the regression function describing the rating of the assessment of the relation of SRHRM practices with the sustainable development of organizations and their implementation in young Polish enterprises computed on the basis of the sample constitutes the basis for concluding on the presence of the said correlation in the whole body, i.e., in all young Polish enterprises.

\section{Conclusions}

Socially responsible activities of enterprises in our modern world have become one of the fundamental elements of assessment of the position of an undertaking on the global market and a unique measure of its competitiveness. Therefore, the CSR concept-and SRHRM as its vital 
component-are becoming increasingly popular. The analysis of source literature demonstrates that SRHRM not only aids the development of sustainable organizations but is also an effective instrument for gaining a competitive advantage, favouring improvement of relations with company employees, increasing their satisfaction, loyalty, and motivation, while boosting both the internal and external company image. Those undertakings that consider SRHRM practices to be a permanent element of the business model they pursue and one of the key competencies are predestined to top the list of global companies and continue to increase their capacity to constantly generate added value. The implementation of the SRHRM concept is, without a doubt, evidence of the HRM system maturity. Maturity in the field of SRHRM may, in turn, be indicative of the general maturity of a given entity in the CSR area. Therefore, analysis of the social aspects of social HRM responsibility should become a more frequent component of assessments of one's developmental potential and enterprise valuations.

To evaluate the scope of implementation of the SRHRM concept in the Polish reality, empirical studies have been conducted on a representative sample of young Polish enterprises. The said studies allowed the positive verification of the following hypotheses:

Hypothesis 1. Socially responsible activities declared by Polish managers in the area of HRM have an irregular relation with the sustainable development of young organizations.

Hypothesis 2. There is correlation between the assessment of the relation of SRHRM practices with the sustainable development of organizations and their implementation in young enterprises.

The analysis of correlations demonstrated a very strong positive correlation between the evaluation of the relation of SRHRM practices with the sustainable development of organizations and their practical implementation. Research demonstrated that the higher the rating of the relation of a given activity in the opinion of Polish managers, the more often it was implemented in the studied companies. This allowed the formulation of the following conclusion: in order to increase the scope of implementation of the SRHRM concept in the Polish reality, it is necessary to raise awareness of the importance of SRHRM practices at managerial level for the sustainable development of organizations.

Furthermore, the empirical studies show that SRHRM practices are adopted relatively frequently by young Polish enterprises. Nonetheless, there seems to be a low level of maturity with respect to the implementation of the SRHRM concept under Polish conditions. The following symptoms are evidence of the above conclusion:

— the focus of a significant rate of the studied entities on obligatory practices, i.e., Those required by law;

-a low rate of entities which hold ethical certificates;

-low interest in the issue of compliance with ethical requirements by contractual partners;

-a widespread lack of developed measurement and reporting procedures regarding SRHRM.

The analysis of regression defining the assessment of the impact of actions concerning CSR in the area of HRM on their realization in young enterprises is the basis for the conclusion that this correlation is present in the whole collection, that is in all Polish enterprises. However, the results cannot be extrapolated directly to any other country, because the work environment in different countries has its own specific conditions. One of the drawbacks of the results gained with the usage of this research method is the fact that the obtained data express only the managers' opinions. However, it should be underlined that the respondents were managers responsible for the realization of the surveyed HR functions in their organizations, that is people having the required knowledge and experience to properly assess the impact of HRM practices on the sustainable development of the enterprises. Sustainable development of enterprises is difficult to be surveyed because it is shaped by many various factors. In this paper the authors concentrated on one of them, that is SRHRM practices. This creates a limitation in the interpretation of the obtained results. 
It appears that in the Polish reality, there are still many entrepreneurs who do not see SRHRM as an effective instrument of HR function improvement. This suggests that the need to disseminate knowledge concerning the usefulness of the society-oriented attitude in the field of human resource management and the emphasis on the relationships between the realization of the said assumptions and the attainment of personnel goals and sustainable development objectives. CSR should feature permanently on the personnel agenda of organizations, for this is the only way in which it can bring long-term positive outcomes as expressed through an accurate perception of an enterprise by its internal and external stakeholders. In the long term, SRHRM activities should be seen as a type of investment which pays off in terms of the increased involvement of employees, improved employee performance, broadened perspectives of development, and strengthened investor confidence, which favors the effective allocation of capital, facilitates the achievement of investment goals, and stimulated sustainable organization-building.

Given the dynamic situation on the labor market, affected by tendencies such as the natural growth rate, the aging of societies, falling unemployment rates, and migration, we should expect SRHRM to be more and more frequently used as an inseparable and permanent element of the personnel strategy. For it must be emphasized that the implementation of the concept may not be limited to an ad hoc participation and may not focus on selected activities only. These must not be pseudo-social initiatives treated as a marketing tool, directed purely at the attainment of image benefits as part of employer branding. Durability (strategic persistence) must be an immanent feature of personnel initiatives taken up as part of SRHRM. Only a long-distance SRHRM strategy, with the potential to become firmly rooted in the organizational culture, may become a foundation for the development of sustainable employees who support the idea of sustainable development of organizations.

Given the advantages of SRHRM implementation and its proven importance for sustainable development of organizations on the one hand and the determined low level of maturity in the field of its practical implementation in the studied entities on the other hand, the authors opine that a significant area for further research is the identification and analysis of factors that precondition the realization of this concept in Polish enterprises. The authors' intention is to continue research directed at the diagnosis of stimuluses and barriers to the implementation of the SRHRM concept.

Author Contributions: E.B. proposed the research concept, reviewed source literature, and wrote the article. A.M.-K. designed the methodology of quantitative research, carried out the statistical analysis of the study findings, and wrote the article.

Acknowledgments: The results of the research carried out under the research theme No. 430/15/S were financed from the science grant granted by the Ministry of Science and Higher Education.

Conflicts of Interest: The authors declare no conflicts of interest.

\section{References}

1. Rosińska-Bukowska, M. Społeczna odpowiedzialność biznesu w procesie kreacji wartości dodanej przedsiębiorstwa. In Kreacja Wartości Przedsiębiorstw. Nowe Trendy i Kierunki Rozwoju; Jabłoński, M., Zamasz, K., Eds.; WSB: Dąbrowa Górnicza, Poland, 2012; pp. 331-357, ISBN 978-83-62897-34-6.

2. Jastrzębska, E. Ewolucja społecznej odpowiedzialności biznesu w Polsce. Kwartalnik Kolegium Ekonomiczno-Społecznego Studia i Prace SGH 2016, 4, 85-101.

3. Jabłoński, A. Zrównoważony Rozwój a Zrównoważony Biznes w Budowie Wartości Przedsiębiorstw Społecznie Odpowiedzialnych; Zeszyty Naukowe Wyższej Szkoły Humanitas; Oficyna Wydawnicza Humanitas: Zarządzanie, Poland, 2010; Volume 2, pp. 15-30.

4. Report of the World Commission on Environment and Development: Our Common Future. Available online: http:/ / www.un-documents.net/our-common-future.pdf (accessed on 27 August 2018).

5. Mazur-Wierzbicka, E. Koncepcja zrównoważonego rozwoju jako podstawa gospodarowania środowiskiem przyrodniczym. In Funkcjonowanie gospodarki polskiej w warunkach integracji i globalizacji; Kopycińska, D., Ed.; Katedra Mikroekonomii Uniwersytetu Szczecińskiego: Szczecin, Poland, 2005; pp. 33-44, ISBN 9788391748763. 
6. Colbert, B.A.; Kurucz, E.C. Three conceptions of triple bottom line business sustainability and the role of HRM. Hum. Resour. Plan. 2007, 30, 21-29.

7. Rimanoczy, I.; Pearson, T. Role of HR in the new world of sustainability. Ind. Commer. Train. 2010, 42, 11-17. [CrossRef]

8. Skowroński, A. Zrównoważony rozwój perspektywą dalszego postępu cywilizacji. Probl. Ekorozw. 2006, 2, 47-57.

9. Elkington, J. Cannibals with Forks: The Triple Bottom Line of Twenty-First Century Business; Capstone: Mankato, MN, USA, 1997.

10. ISO 26000:2010 Guidance on Social Responsibility. Available online: https://www.iso.org/standard/42546 .html (accessed on 17 May 2018).

11. Adamczyk, J.; Nitkiewicz, T. Programowanie Zrównoważonego Rozwoju Przedsiębiorstw; PWE: Warszawa, Poland, 2007; ISBN 83-208-1705-8. (In Polish)

12. Porter, M.E.; Kramer, M.R. Tworzenie wartości dla biznesu i społeczeństwa. Harv. Bus. Rev. Polska 2011, 5, 80-87. (In Polish)

13. Rok, B. Odpowiedzialny Biznes w Nieodpowiedzialnym Świecie; Akademia Rozwoju Filantropii w Polsce, Forum Odpowiedzialnego Biznesu: Warszawa, Poland, 2001. (In Polish)

14. Carroll, A.B. Carroll's Pyramid of CSR: Taking Another Look. 2016. Available online: https://doi.org/10.1 186/s40991-016-0004-6 (accessed on 15 February 2019).

15. Hart, S. Capitalism at the Crossroads: Aligning Commerce, Earth, and Humanity, 2nd ed.; FT Press: Upper Saddle River, NJ, USA, 2007.

16. Pichola, I.; Nocoń, A. Jak Angażować Interesariuszy Firmy do Budowania jej Wartości, Odpowiedzialny Biznes; Harvard Business Review: Warszawa, Poland, 2008. (In Polish)

17. Szumiak-Samolej, J. Odpowiedzialny Biznes w Gospodarce Sieciowej; Poltext: Warszawa, Poland, 2013; ISBN 978-83-7561-360-5. (In Polish)

18. Hys, K.; Hawrysz, L. Corporate Social Responsibility Reporting. China-USA Bus. Rev. 2012, 11, 1515-1524.

19. Hediger, W. Welfare and capital-theoretic foundations of corporate social responsibility and corporate sustainability. J. Socio-Econ. 2010, 39, 518-526. [CrossRef]

20. Cohen, E.; Taylor, S.; Muller-Camen, M. HRM's Role in Corporate Social and Environmental Sustainability; SHRM Report: Alexandria, VA, USA, 2012.

21. Jamali, D.; Safieddine, A.M.; Rabbath, M. Corporate Governance and Corporate Social Responsibility Synergies and Interrelationships. Corp. Gov. Int. Rev. 2008, 16, 443-459. [CrossRef]

22. Buchholz, A.K.; Brown, J.; Shabana, K. Corporate governance and corporate social responsibility. The Oxford Handbook of Corporate Social Responsibility; Crane, A., McWilliams, A., Matten, D., Moon, J., Siegel, D.S., Eds.; Oxford University Press: New York, NY, USA, 2008; pp. 327-345, ISBN 9780199211593.

23. Harjoto, M.A.; Jo, H. Corporate Governance and CSR Nexus. J. Bus. Ethics 2011, 100, 45-67. [CrossRef]

24. Wilewska, M. Corporate governance i corporate social responsibility-Powiązania i wzajemne relacje. Zarzadzanie Finans. 2013, 2, 67-75.

25. Giroud, X.; Mueller, H. Corporate governance, product market competition, and equity prices. J. Financ. 2011, 66, 563-600. [CrossRef]

26. Coles, J.L.; Li, Z.; Wang, A.Y. Industry Tournament Incentives. Rev. Financial Stud. 2018, 31, 1418-1459. [CrossRef]

27. Core, J.; Guay, W. The use of equity grants to manage optimal equity incentive levels. J. Account. Econ. 1999, 28, 151-184. [CrossRef]

28. Li, Z. Mutual monitoring and corporate governance. J. Bank. Financ. 2014, 45, 255-269.

29. Dyllick, T.; Hockerts, K. Beyond the Business Case for Corporate Sustainability. Bus. Strategy Environ. 2002, 11, 130-141. [CrossRef]

30. Spreitzer, G.; Porath, C.L.; Gibson, C.B. Toward Human Sustainability: How to Enable More Thriving at Work. Organ. Dyn. 2012, 41, 155-162. [CrossRef]

31. Wilkinson, A.; Hill, M.; Gollan, P. The sustainability debate. Int. J. Oper. Prod. Manag. 2001, 12, 1492-1502. [CrossRef]

32. Ehnert, I. Sustainability and Human Resource Management: Reasoning and Applications on Corporate Websites. Eur. J. Int. Manag. 2009, 4, 419-438. [CrossRef] 
33. Renwick, D.; Redman, T.; Maguire, D. Green HRM: A Review, Process Model, and Research Agenda. Discussion Paper No 2008.01. The University of Sheffield, April 2008. Available online: https:/ / www.sheffie ld.ac.uk/polopoly_fs/1.120337! / file/Green-HRM.pdf (accessed on 27 August 2018).

34. Jabbour, J.; Santos, F. The Central Role of Human Resource Management in the Search for Sustainable Organizations. Int. J. Hum. Resour. Manag. 2008, 12, 2133-2154. [CrossRef]

35. Wirtenberg, J.; Harmon, J.; Fairfield, K.D. HR's Role in Building a Sustainable Enterprise: Insights from Some of the World's Best. Hum. Resour. Plan. 2007, 30, 10-20.

36. Spooner, K.; Kaine, S. Defining Sustainability and Human Resource Management. Int. Employ. Relat. Rev. 2010, 2, 70-81.

37. Obrad, C.; Gherhes, V. A Human Resources Perspective on Responsible Corporate Behavior. Case Study: The Multinational Companies in Western Romania. Sustainability 2018, 10, 726. [CrossRef]

38. Harmon, J.; Fairfield, K.D.; Wirtenberg, J. Missing an Opportunity: HR Leadership and Sustainability. People Strategy 2010, 33, 16-21.

39. Glade, B. Human Resources: CSR and Business Sustainability-HR's Leadership Role. N. Z. Manag. 2008, 9, 51-52.

40. Jabbour, C.J.C.; Santos, F.C.A.; Nagano, M.C. Environmental Management System and Human Resource Practices: Is there a link between them in four Brazilian Companies? J. Clean. Prod. 2008, 17, 1922-1925. [CrossRef]

41. Liebowitz, J. The role of HR in achieving a sustainability culture. J. Sustain. Dev. 2010, 3, 50-57. [CrossRef]

42. Kramar, R. Beyond strategic human resource management: Is sustainable human resource management the next approach? Int. J. Hum. Resour. Manag. 2014, 25, 1069-1089. [CrossRef]

43. Ehnert, I.; Harry, W.; Zink, K.J. Sustainability and HRM: An introduction to the field. In Sustainability and Human Resource Management: Developing Sustainable Business Organizations; Ehnert, I., Harry, W., Zink, K.J., Eds.; Springer: Heidelberg, Germany, 2014; pp. 3-32, ISBN 978-3-642-37524-8.

44. Pabian, A. Zrównoważone zarządzanie zasobami ludzkimi. Zarys problematyki. Zesz. Nauk. Politech. Częstochowskiej Zarządzanie 2015, 17, 7-16. (In Polish)

45. Pocztowski, A. Zrównoważone zarządzanie zasobami ludzkimi w teorii i praktyce. Zarządzanie Finans. 2016, 2, 303-314. (In Polish)

46. Pabian, A. Sustainable personnel-Pracownicy przedsiębiorstwa przyszłości. Zarzadzanie Zasobami Ludzkimi 2011, 5, 9-18. (In Polish)

47. Cohen, S. Sustainability Management; Columbia University Press: New York, NY, USA, 2011; ISBN 9780231152587.

48. Majewski, D. Zrównoważeni pracownicy i ich satysfakcja z pracy. Edukacja Ekonomistów i Menedżerów 2012, 2, 155-167. (In Polish) [CrossRef]

49. Hart, S.L.; Milstein, M.B. Creating sustainable value. Acad. Manag. Executive 2003, 2, 56-67. [CrossRef]

50. Grudzewski, W.M.; Hejduk, I.K.; Sankowska, A.; Wańtuchowicz, M. Sustainability w Biznesie, Czyli Przedsiębiorstwo Przyszłości: Zmiany Paradygmatów i Koncepcji Zarządzania; Warszawa: Poltext, Poland, 2010; ISBN 978-83-7561-257-8. (In Polish)

51. Abidin, N.Z.; Pasquire, Ch.L. Revolutionize value management: A mode towards sustainability. Int. J. Proj. Manag. 2007, 25, 275-282. [CrossRef]

52. Burchard-Dziubińska, M. Zrównoważony biznes-dlaczego tak trudno o sukces? In Przedsiębiorstwo w Warunkach Zrównoważonej Gospodarki; Powichrowska, B., Ed.; Wyższa Szkoła Ekonomiczna: Białystok, Poland, 2011; ISBN 978-83-61247-38-8. (In Polish)

53. Vickers, M.R. Business Ethics and the HR Role: Past, Present, and Future. Hum. Resour. Plan. 2005, $28,26-32$.

54. Taylor, S.; Osland, J.; Egri, C.P. Guest Editors' Introduction: Introduction to HRM's Role in Sustainability: Systems, Strategies, and Practices. Hum. Resour. Manag. 2012, 5, 789-798. [CrossRef]

55. Haugh, H.M.; Talwar, A. How Do Corporations Embed Sustainability Across the Organization? Acad. Manag. Learn. Educ. 2010, 9, 384-396. [CrossRef]

56. Sharma, S.; Sharma, J.; Devi, A. Corporate social responsibility: The key role of human resource management. Bus. Intell. J. 2009, 2, 205-213. 
57. Jang, S.; Ardichvili, A. The Role of HRD in Embedding Corporate Social Responsibility (CSR) in Organizations Working Paper submitted to the 17th International Research Conference on HRD across Europe 2016, Stream: Scholarly Practitioner Research. Available online: https:/ / www.ufhrd.co.uk/wordpr ess/wp-content/uploads/2016/10/paper_125.pdf (accessed on 30 August 2018).

58. Fenwick, T. Corporate Social Responsibility and HRD. In Handbook of Human Resource Development; Chalofsky, N.E., Rocco, T.S., Morris, M.L., Eds.; John Wiley: Hoboken, NJ, USA, 2014; pp. 164-179, ISBN 978-1-118-45402-2.

59. Pfeffer, J. Building sustainable organizations: The human factor. Acad. Manag. Perspect. 2010, 24, 34-45.

60. Ardichvili, A. The Role of HRD in CSR, Sustainability, and Ethics a Relational Model. Hum. Resour. Dev. Rev. 2013, 4, 456-473. [CrossRef]

61. Garavan, T.; McGuire, D. Human resource development and society: Human resource development's role in embedding corporate social responsibility, sustainability, and ethics in organizations. Adv. Dev. Hum. Resour. 2010, 5, 487-507. [CrossRef]

62. Wilcox, T. Human Resource Development as an Element of Corporate Social Responsibility. Asia Pac. J. Hum. Resour. 2006, 44, 184-196. [CrossRef]

63. Inyang, B.J.; Awa, H.O.; Enuoh, R.O. CSR-HRM Nexus: Defining the Role Engagement of the Human Resources Professionals. Int. J. Bus. Soc. Sci. 2011, 5, 118-126.

64. Boudreau, J.W.; Ramstad, P.M. Talentship. Talent Segmentation and Sustainability: A New HR Decision Science Paradigm for a New Strategy Definition. Hum. Resour. Manag. 2005, 2, 129-136. [CrossRef]

65. Ehnert, I. Sustainable Human Resource Management: A Conceptual and Exploratory Analysis from a Paradox Perspective; Physica-Verlag: Heidelberg, Germany, 2009; ISBN 978-3-7908-2187-1.

66. Guest, D.E. Human Resource Management and Performance: Still Searching for Some Answers. Hum. Resour. Manag. J. 2011, 21, 3-13. [CrossRef]

67. Thom, N.; Zaugg, R. Nachhaltiges und innovatives Personalmanagement: Spitzengruppenbefragung in europäischen Unternehmungen und Institutionen. In Nachhaltiges Innovationsmanagement; Schwarz, E.J., Ed.; Gabler: Wiesbaden, Germany, 2004; pp. 217-245.

68. Voegtlin, Ch.; Greenwood, M. Corporate social responsibility and human resource management: A systematic review and conceptual analysis. Hum. Resour. Manag. Rev. 2016, 3, 181-197. [CrossRef]

69. Ardichvili, A. Sustainability of nations, communities, organizations and individuals: The role of HRD. Hum. Resour. Dev. Int. 2011, 4, 371-374. [CrossRef]

70. Shen, J. Developing the concept of socially responsible international human resource management. Int. J. Hum. Resour. Manag. 2011, 6, 1351-1363. [CrossRef]

71. Greenwood, M. Ethics and HRM: A review and conceptual analysis. J. Bus. Ethics 2002, 3, 261-278. [CrossRef]

72. Cooke, F.L.; He, Q.L. Corporate social responsibility and HRM in China: A study of textile and apparel enterprises. Asia Pac. Bus. Rev. 2010, 3, 355-376. [CrossRef]

73. Dupont, C.; Ferauge, P.; Giuliano, R. The Impact of Corporate Social Responsibility on Human Resource Management: GDF SUEZ's Case. Int. Bus. Res. 2013, 12, 145-155. [CrossRef]

74. De Stefano, F.; Bagdadli, S.; Camuffo, A. The HR role in corporate social responsibility and sustainability: A boundary-shifting literature review. Hum. Resour. Manag. 2018, 2, 549-566. [CrossRef]

75. Jamali, D.R.; Dirani, A.E.; Harwood, I.A. Exploring Human Resource Management Roles in Corporate Social Responsibility: The CSR-HRM Co-creation Model. Bus. Ethics A Eur. Rev. 2015, 2, 125-143. [CrossRef]

76. Becker, W.S.; Carbo, J.A.; Langella, I.M. Beyond self-interest: Integrating social responsibility and supply chain management with human resource development. Hum. Resour. Dev. Rev. 2010, 2, 144-168. [CrossRef]

77. Becker, W.S. Are you leading a socially responsible and sustainable human resource function? People Strategy 2011, 34, 18-23.

78. Preuss, L.; Haunschild, A.; Matten, D. The rise of CSR: Implications for HRM and employee representation. Int. J. Hum. Resour. Manag. 2009, 4, 953-973. [CrossRef]

79. Garavan, T.N.; Heraty, N.; Rock, A.; Dalton, E. Conceptualizing the behavioral barriers to CSR and CS in organizations: A typology of HRD interventions. Adv. Dev. Hum. Resour. 2010, 5, 587-613. [CrossRef]

80. Bhattacharya, C.B.; Sen, S.; Korschun, D. Using corporate social responsibility to win the war for talent. Sloan Manag. Rev. 2008, 2, 37-44. 
81. Davies, I.A.; Crane, A. Corporate social responsibility in small-and medium-size enterprises: Investigating employee engagement in fair trade companies. Bus. Ethics A Eur. Rev. 2010, 2, 126-139. [CrossRef]

82. Gond, J.P.; Igalens, J.; Swaen, V.; El Akremi, A. The human resources contribution to responsible leadership: An exploration of the CSR-HR interface. J. Bus. Ethics 2011, 98, 115-132. [CrossRef]

83. Wachowiak, P. Wrażliwość Społeczna Przedsiębiorstwa. Analiza i Pomiar; Oficyna Wydawnicza SGH: Warszawa, Poland, 2013; ISBN 978-83-7378-851-0. (In Polish)

84. Paliszkiewicz, J. Zaufanie w Zarządzaniu; PWN: Warszawa, Poland, 2013; ISBN 978-83-01-19371-3. (In Polish)

85. Greening, D.W.; Turban, D.B. Corporate social Performance as a competitive advantage in attracting a quality workforce. Bus. Soc. 2000, 39, 254-280. [CrossRef]

86. Odriozola, M.D.; Martín, A.; Luna, L. The relationship between labour social responsibility practices and reputation. Int. J. Manpow. 2015, 36, 236-251. [CrossRef]

87. Valentine, S.; Fleischman, G. Ethics programs, perceived corporate social responsibility and job satisfaction. J. Bus. Ethics 2008, 77, 159-172. [CrossRef]

88. Lindgreen, A.; Swaen, V. Corporate social responsibility. Int. J. Manag. Rev. 2010, 12, 1-7. [CrossRef]

89. Fapohunda, T.M. The Human Resource Management Dimensions of Corporate Social Responsibility. Eur. J. Res. Reflect. Manag. Sci. 2015, 2, 1-14.

90. Bombiak, E.; Marciniuk-Kluska, A. Green Human Resource Management as a Tool for the Sustainable Development of Enterprises: Polish Young Company Experience. Sustainability 2018, 10, 1739. [CrossRef]

91. Rogowski, R. Praktyka wdrażania CSR w polskich przedsiębiorstwach w opinii doradców. Ann. Ethics Econ. Life 2016, 19, 37-54. (In Polish) [CrossRef]

92. Himmelberg, C.; Hubbard, R. Incentive Pay and the Market for CEOS: An Analysis of Pay-for-Performance Sensitivity (June 2000). Presented at Tuck-JFE Contemporary Corporate Governance Conference; 2000. Available online: https:/ / ssrn.com/abstract=2360891 (accessed on 2 January 2019).

93. Dang, C.; Li, F. Measuring Firm Size in Empirical Corporate Finance. J. Bank. Financ. 2018, 86, $159-176$. [CrossRef]

94. Stankevičiūtè, Ž.; Savanevičienè, A. Designing Sustainable HRM: The Core Characteristics of Emerging Field. Sustainability 2018, 10, 4798. [CrossRef]

95. Raport Odpowiedzialny Biznes w Polsce 2017. Dobre Praktyki. Available online: http://odpowiedzialnybi znes.pl/publikacje/raport-2017/ (accessed on 7 September 2018). (In Polish)

96. Wolska, G. Zaangażowanie przedsiębiorstw w realizację koncepcji społecznej odpowiedzialności biznesu. Studia Ekonomiczne. Zeszyty Naukowe Uniwersytetu Ekonomicznego w Katowicach 2015, 236, 85-95. (In Polish)

97. Furmańska-Maruszak, A.; Sudolska, A. Relacje z pracownikami jako obszar wdrażania CSR. Organ. Kier. 2017, 2, 253-267. (In Polish)

98. Raport Odpowiedzialny Biznes w Polsce 2016. Dobre Praktyki. Available online: http:/ / odpowiedzialnybi znes.pl/publikacje/raport-2016/ (accessed on 7 September 2018). (In Polish)

99. Raport Odpowiedzialny Biznes w Polsce 2011. Dobre Praktyki. Available online: http:/ / odpowiedzialnybi znes.pl/wp-content/uploads/2014/01/Raport2011.pdf (accessed on 7 September 2018). (In Polish)

100. Głuszek, E. Wykorzystywanie inicjatyw społecznych w budowaniu atrybutów dobrej reputacji przedsiębiorstwa. Prace Naukowe Uniwersytetu Ekonomicznego we Wrocławiu 2013, 288, 22-36. (In Polish)

101. Raport Odpowiedzialny Biznes w Polsce 2010. Dobre Praktyki. Available online: http:/ / odpowiedzialnybi znes.pl/wp-content/uploads/2014/02/Raport_odpowiedzialny_biznes_w_Polsce_2010-1301645271.pdf (accessed on 7 September 2018). (In Polish)

102. Wojtysiak-Sowa, E. Obowiązkowy Raport CSR? Polskie Firmy nie są na Niego Gotowe! Available online: http: //jbcomm.pl/aktualnosci/obowiazkowy-raport-csr-polskie-firmy-nie-sa-na-niego-gotowe/ (accessed on 28 August 2018).

103. Ehnert, I.; Parsa, S.; Roper, I.; Wagner, M.; Muller-Camen, M. Reporting on sustainability and HRM: A comparative study of sustainability reporting practices by the world's largest companies. Int. J. Hum. Resour. Manag. 2016, 27, 88-108. [CrossRef] 
104. Partnerstwo na rzecz realizacji celów zrównoważonego rozwoju w Polsce. Ministerstwo Przedsiębiorczości i Technologii. Available online: https://www.mpit.gov.pl/strony/zadania/zrownowazony-rozwoj/a genda-2030/partnerstwo-na-rzecz-realizacji-celow-zrownowazonego-rozwoju-w-polsce/ (accessed on 24 August 2018).

105. Wróbel, M. Raportowanie społecznej odpowiedzialności w Polsce w świetle unormowań Dyrektywy Parlamenty Europejskiego i Rady 2014/95/UE. Zesz. Nauk. Wyższej Szkoły Humanit. Zarzadzanie 2016, 2, 83-94. (In Polish) [CrossRef] 